Burbii Anastasiia,

Postgraduate, Leading legal adviser,

State Research Institute MIA Ukraine, Kyiv, Ukraine

ORCID ID 0000-0003-4866-321X

\title{
COMMON FEATURES OF CRIMES AGAINST ELECTORAL RIGHTS
}

The article analyzes objective and subjective signs of crimes against the electoral rights of citizens, which makes it possible to distinguish them among the whole array of criminal offenses. The ambiguity in the interpretation of the constituent characteristics of these crimes is emphasized. Attention focused on the incoherence of approaches to understanding the object of these crimes in the science of criminal law, both in general theory and within the limits of its allocation in the context of criminal attacks on citizens' electoral rights. At the same time, there is a certain contradiction at the level of legislative inclusion of voting rights to other personal human and civil rights and freedoms, having found themselves in the process of grouping these crimes within the Criminal Code of Ukraine. Such a grouping clearly contradicts fundamental legal notions of human rights. Moreover, the author supports the position of placing social relations as the most universal category in the basis of objective determination. Allegedly, this is because representing the object of such crimes through a system of values is impossible, given the complexity and multidimensional nature of the electoral process. The specified allows drawing a conclusion about the necessity to separate crimes against electoral rights of citizens into an independent structural subdivision within the framework of the criminal law. In analyzing the objective signs of these crimes, most are committed through active action, but there may be cases of inactivity. In such a case we are talking about an illegal abstention from necessary actions, as a result of which electoral relations are damaged. The problems existing in the legislation to define a special subject of certain crimes against the electoral rights of citizens are outlined. The inconsistency of the legislator in relation to the identification of a 
member of the election commission as an official is revealed; it can negatively affect the qualification of crimes of this type.

Keywords: electoral rights, public relations, crime composition, infringement object, actions, intent.

\section{REFERENCES}

1. Shliakhtun P.P. (2008) Konstytutsiine pravo Ukrainy. "Constitutional Law of Ukraine". K.: Education of Ukraine, CST. 592 p. [in Ukrainian].

2. Frytskyi O.F. (2006) Konstytutsiine pravo Ukrainy. "Constitutional Law of Ukraine": Textbook. K.: Yurinkom Inter. 512 p. [in Ukrainian].

3. Us O.V. (2016) Kryminalno-pravova otsinka vchynenoho diiannia za oznakamy obiekta skladu zlochynu. "Criminal law assessment of the act on the basis of the object of the crime. Uzhgorod National University Scientific Bulletin. Iss. No. 41, vol. 2, P. 145-150. [in Ukrainian].

4. Glistin V.K. (1979) Problema uholovno-pravovoi okhrany obshchestvennykh otnoshenii (obiekt i kvalifikatsiia prestuplenii). "The problem of criminal legal protection of public relations (object and qualification of crimes)": monograph. Leninhrad. 84 p. [in Russian].

5. Aleksandrov Yu.V., Dudorov O.O., Klymenko V.A. ta in. (2009) Kryminalne pravo Ukrainy. Osoblyva chastyna. "Criminal law of Ukraine”. Special part: textbook / ed. M.I. Melnik, V.A. Klymenko. 3rd ed., Revised and supplemented. Kyiv: Attika. 744 p. [in Ukrainian].

6. Tatsii V.Ya. (1994) Obiekt i predmet zlochynu v kryminalnomu pravi Ukrainy. "The object and object of crime in the criminal law of Ukraine: teach. manual. Kharkiv: Ukr. Juridic. Acad. 267 p. [in Ukrainian].

7. Kharchenko V.B., Perekrestov F.B. (2001) Uholovnoie pravo Ukrainy. Osobiennaia chast: novoie zakonodatielstvo v voprosakh i otvietakh: konspekt liektsii. "Criminal law of Ukraine. Special part: new legislation in questions and answers": lecture notes. Kharkov: Scorpio. 237 p. [in Russian]. 
8. Kryvulia O.M., Kuts V.M. (1997) Chy mozhut buty suspilni vidnosyny obiektom zlochynu?. "Could a social relationship be a crime?" Internal affairs university newsletter. Iss. 2. Kharkov. P. 70-74. [in Ukrainian].

9. Lykhova S.Ya. (2000) Kryminalno-pravova okhorona vyborchykh prav hromadianyna ta shliakhy yii vdoskonalennia. "Criminal protection of the electoral rights of the citizen and ways of its improvement". NaUKMA Scientific Notes. Juridical Sciences. Vol. 18. P. 29-35. [in Ukrainian].

10. Lykhova S. (2000) Konstytutsiino-pravovyi instytut osnovnykh prav i svobod liudyny yak obiekt kryminalno-pravovoi okhorony. "Constitutional-Legal Institute of Fundamental Rights and Freedoms of Human Being as an Object of Criminal Legal Protection". Legal Bulletin of Ukraine. No. 25. P. 21-24. [in Ukrainian].

11. Tagantsev N.S. (1887) Liektsii po russkomu uholovnomu pravu. Chast obshchaia. "Lectures on Russian criminal law". Part is common. Iss. 1. Petersburh. [in Russian].

12. Andrushko P.P. (2007) Zlochyny proty vyborchykh prav hromadian ta yikh prava braty uchast u referendumi: kryminalno-pravova kharakterystyka. "Crimes against the suffrage of citizens and their right to participate in the referendum: criminal characteristics": monograph. K.: CST. 328 p. [in Ukrainian].

13. Medina L.P. (2004) Kryminalno-pravova kharakterystyka zlochyniv proty vyborchykh prav hromadian Ukrainy (st.st. 157, 158, 159 KK Ukrainy): dys. ... kand. yuryd. nauk: 12.00.08. "Criminal and Legal Characteristics of Crimes Against the Electoral Rights of Citizens of Ukraine (Articles 157, 158, 159 of the Criminal Code of Ukraine)": diss. ... Ph. D. In Law: 12.00.08. K. 226 p. [in Ukrainian].

14. Zhelik M.B. (2018) Pryiniattia propozytsii, obitsianky abo oderzhannia nepravomirnoi vyhody: kryminalno-pravova kharakterystyka: dys. ... kand. yuryd. nauk: 12.00.08. "Acceptance of an offer, promise or receipt of undue benefit: criminal characteristic: diss. Ph. D in Law: 12.00.08. L. 20 p. [in Ukrainian].

15. Tuliakov V.O., Myroshnychenko N.A., Balobanova D.O. (2014) Kryminalne pravo Ukrainy. Zahalna chastyna: tekst lektsii: Zakon. Zlochyn. Vidpovidalnist. "Criminal law of Ukraine. General part: lecture text: Law. Crime. 
Responsibility". National University "Odesa Law Academy". Odessa: Juridical Literature. 128 p. [in Ukrainian].

16. Vozniuk A.A. (2016) Kryminalne pravo Ukrainy. Zahalna chastyna: konspekt lektsii; vstupne slovo d-ra. yuryd. nauk., prof. O.O. Dudorova. "Criminal law of Ukraine". General part: lecture notes; introductory word of Doctor of Juridical Sciences., Professor O.O. Dudorov. Kyiv: Education of Ukraine. 236 p. [in Ukrainian].

17. Kozachenko I.P., Kostenko O.M., Matviichuk V.K. ta in. (2006) Kryminalne pravo Ukrainy: Zahalna chastyna: Praktykum. "Criminal Law of Ukraine: General: Workshop”: Teaching tool. Kyiv: KST. 432 p. [in Ukrainian].

18. Baulin Yu.V., Borysov V.I., Tiutiuhin V.I. ta in. (2010) Kryminalne pravo Ukrainy: Zahalna chastyna: pidruchnyk. "Criminal law of Ukraine: Common part": textbook / ed. V.V. Stashisa, V.Ya. Tatcia. Iss. 4 , revised and supplemented by Kh: Pravo. [in Ukrainian].

19. Aleksandrov Yu.V., Dudorov O.O., Klymenko V.A. ta in. (2009) Kryminalne pravo Ukrainy. Osoblyva chastyna. "Criminal law of Ukraine. Special part": textbook / edited by M.I. Melnika, V.A. Klimenko. 3rd edition, revised and supplemented by Kyiv: Atika. 744 p. [in Ukrainian].

20. Kryminalne pravo Ukrainy. Zahalna chastyna. "Criminal law of Ukraine. Common part" / ed. M. Bazhanova, V. Stashisa, V. Tatsii. Kyiv - Kharkiv: Jurinkom Inter-Law, 2002-2003. 290 p. [in Ukrainian].

21. Matyshevskyi P. (2000) Kryminalne pravo Ukrainy. Zahalna chastyna. "Criminal Law of Ukraine. The general part": textbook. Kyiv: Yurincom Inter. 426 p. [in Ukrainian].

22. Naukovi pratsi Odeskoi natsionalnoi yurydychnoi akademii. "Scientific works of the Odessa National Law Academy" / Editor-in-Chief S.V. Kivalov; Ministry of Education and Science of Ukraine, National University "Odesa Law Academy". Odessa: Juridical Literature, 2017. T. 19. 482 p. [in Ukrainian].

23. Antypov V.I., Topchii V.V. (2017) Kryminalno-pravova kvalifikatsiia posiahan na vyborchi ta referendni prava. "Criminal qualification of encroachments on suffrage and reference rights". Vinnytsia: Nilan LTD. 116 p. [in Ukrainian]. 
24. Yas A.O. (2015) Kryminalna vidpovidalnist za pereshkodzhannia zdiisnenniu vyborchoho prava abo prava braty uchast u referendumi, roboti vyborchoi komisii abo komisii z referendumu chy diialnosti ofitsiinoho sposterihacha (stattia 157 Kryminalnoho kodeksu Ukrainy). "Criminal liability for impeding the exercise of the right to vote or to participate in a referendum, the work of an election commission or a referendum commission or the activities of an official observer (Article 157 of the Criminal Code of Ukraine)": diss. Ph. D. in Law: 12.00.08. K. 211 p. [in Ukrainian].

25. Miahkov M.O. (2006) Pereshkodzhannia zdiisnenniu vyborchoho prava: problemy kryminalnoi vidpovidalnosti. "Obstruction to suffrage: Criminal liability issues: author. diss. Ph. D. in Law. K .: National Academy of Sciences of Ukraine; University of State and Law. V.M. Koretsky. 20 p. [in Ukrainian].

26. Kostrytskyi V.V. (2015) Kryminalna vidpovidalnist za pereshkodzhannia zdiisnenniu vyborchoho prava abo prava braty uchast u referendumi, roboti vyborchoi komisii abo komisii z referendumu chy diialnosti ofitsiinoho sposterihacha (stattia 157 Kryminalnoho kodeksu Ukrainy). "Criminal liability for impeding the exercise of the right to vote or to participate in a referendum, the work of an election commission or a referendum commission or the activities of an official observer (Article 157 of the Criminal Code of Ukraine)": diss. Ph. D. in Law: 12.00.08. 250 p. [in Ukrainian]. 